\title{
Fusion Proteins of Single-Chain Variable Fragments Derived from Phage Display Libraries Are Effective Reagents for Routine Diagnosis of Potato Leafroll Virus Infection in Potato
}

\author{
R. L. Toth, K. Harper, M. A. Mayo, and L. Torrance
}

Scottish Crop Research Institute, Invergowrie, Dundee, DD2 5DA United Kingdom.

Accepted for publication 25 July 1999.

\begin{abstract}
Toth, R. L., Harper, K., Mayo, M. A., and Torrance, L. 1999. Fusion proteins of single-chain variable fragments derived from phage display libraries are effective reagents for routine diagnosis of potato leafroll virus infection in potato. Phytopathology 89:1015-1021.

A panel of 11 different single-chain variable fragment antibodies (scFv) that bind to potato leafroll virus (PLRV) has been studied to assess each one's suitability as practical diagnostic tools. The scFv, previously obtained from naive phage display libraries, were expressed in Escherichia coli as fusion proteins. The fusion proteins comprised $\mathrm{scFv}$ joined to either the human light chain kappa constant domain $\left(\mathrm{C}_{\mathrm{L}}\right)$, an amphipathic helix (Zip), a combination of $\mathrm{C}_{\mathrm{L}}$ and $\mathrm{Zip}$, or alkaline phosphatase (AP/S). The fusion proteins were tested for their ability to detect, or trap on enzymelinked immunosorbent assay (ELISA) plates, PLRV in extracts of infected potato leaves. The tests done with the different $\mathrm{scFv}$ fusion proteins were compared with a standard triple-antibody sandwich (TAS)-ELISA that employs a rabbit polyclonal antibody preparation to coat microtiter plates

and a monoclonal antibody, SCR3, to detect PLRV. Of $11 \mathrm{scFvC}_{\mathrm{L}}$ fusion proteins, 7 detected PLRV as readily as SCR3 when used as detecting antibodies in TAS-ELISA. The limit of detection of purified PLRV for the different $\mathrm{scFvC}_{\mathrm{L}}$ fusion proteins ranged from 250 to $5 \mathrm{ng} / \mathrm{ml}$; that for $\mathrm{SCR} 3$ is $5 \mathrm{ng} / \mathrm{ml}$. Of the $11 \mathrm{scFv}, 4$ cross-reacted with some other luteoviruses. Several $\mathrm{scFvC}_{\mathrm{L}}$ and $\mathrm{scFvC}_{\mathrm{L}} \mathrm{Zip}$ fusion proteins trapped PLRV from extracts of infected potato leaves as effectively as the polyclonal antibody preparation. Four $\mathrm{scFv}$ fusion proteins were used in a stem print assay to detect PLRV, and the results were similar to those obtained in tests using SCR3. The $\mathrm{scFvC}_{\mathrm{L}}$ fusion proteins retained activity for at least 6 months at $4^{\circ} \mathrm{C}$, and all $\mathrm{scFv}$ fusion proteins were fully active on reconstitution after lyophilization. A fully recombinant ELISA was devised that detected PLRV in extracts of infected potato, with results comparable to those obtained using the standard TAS-ELISA. The advantages of using $\mathrm{scFv}$ fusion proteins for the routine detection of plant viruses include the ability to produce large quantities of reagents cheaply in bacterial fermenters and to incorporate them into standardized tests.
\end{abstract}

Antibodies (both polyclonal and monoclonal) have been used extensively in tests to detect a wide range of plant pathogens, including plant viruses (24). Monoclonal antibodies (MAbs) are superior to polyclonal antibodies because they can provide a constant supply of specific diagnostic reagents. However, MAbs are expensive to produce and to maintain, because specialized cell cultures and costly low-temperature storage facilities are required. Moreover, during storage, some hybridoma cell lines can die and others can lose their capacity to secrete specific antibodies.

Phage display libraries constructed from immunoglobulin genes obtained from nonimmunized donors (naive libraries) have provided a source of antibody fragments (single-chain variable fragments $[\mathrm{scFv}]$ ) that have been shown to have high affinities for antigens and to have binding properties equivalent to those of antibodies produced by immunized animals $(20,26)$. Recombinant antibodies can be produced from libraries of such antibody fragments quickly ( 2 to 4 weeks) by methods that do not require the use of animals. DNA from clones selected from libraries can be stored indefinitely and is readily propagated. Thus, it can provide an unlimited source of reagent.

Potato leafroll virus (PLRV, family Luteoviridae, genus Polerovirus) is one of the most economically important viruses that infect potato crops (7). Enzyme immunoassays are used for the detection of PLRV in potato crops and play an important role in monitoring the production of virus-free stocks of "seed" potato tubers. Assays employed by different plant health agencies are not

Corresponding author: L. Torrance; E-mail address: 1torra@scri.sari.ac.uk

Publication no. P-1999-0909-01R

(C) 1999 The American Phytopathological Society uniform because different antibody preparations are used. Also, most antibody preparations are obtained from rabbit polyclonal sera, which are inherently more variable than MAbs. The ability to produce scFv in Escherichia coli $(8,14)$ provides an opportunity to obtain large quantities of defined and standardized reagents, quickly and cheaply.

Previously, a scFv against PLRV was obtained from a phage display library (16). The scFv was expressed in E. coli fused to alkaline phosphatase (AP) and the resultant fusion protein used in enzyme-linked immunosorbent assay (ELISA) to detect PLRV in extracts of Physalis floridana (4). However, the absorbance values were weak compared with those obtained in tests using a polyclonal antibody preparation. This article describes experiments with a panel of $\mathrm{scFv}$, obtained from two phage display libraries, that react with PLRV. The scFv were expressed as fusions with different proteins, including a mutated AP with a greater specific activity than wild type (9), for use in tests to detect PLRV in potato. The fusion proteins were compared with reagents in current use both for coating microtiter plates for trapping PLRV and as primary antibodies to detect PLRV in potato leaf extracts by ELISA and stem printing. By combining different $\mathrm{scFv}$ fusion proteins, we have devised a fully recombinant ELISA for PLRV that detects PLRV as readily as tests done with the currently used reagents.

\section{MATERIALS AND METHODS}

scFv fusion proteins. Ten scFv (code-named V1 to V9 and N11) were obtained after selections against immobilized PLRV from either a "nonimmunized" human scFv library (V1 to V9) (26) or a semisynthetic human scFv library (N11) (16). scFv V1 to V7 and N11 were selected against PLRV particles, whereas scFv V8 and V9 
were selected against dissociated coat protein subunits (6). Also, the $\mathrm{scFv}$ N10 selected against PLRV particles (4) was subcloned into some of the different expression vectors described below, giving a total of $11 \mathrm{scFv}$ for analysis as different fusion proteins. The methods for selection of $\mathrm{scFv}$ from phage display libraries are described in Harper et al. $(5,6)$. Briefly, one round of selection involved coating immunotubes (MaxiSorp; Nalge Nunc International, Rochester, NY) with preparations of PLRV particles in phosphate-

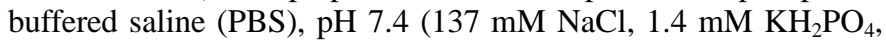
$4.3 \mathrm{mM} \mathrm{Na} \mathrm{HPO}_{4} \cdot 12 \mathrm{H}_{2} \mathrm{O}$, and $2.7 \mathrm{mM} \mathrm{KCl}$ ), or carbonate coating buffer, pH 9.6 (14.5 mM Na $2 \mathrm{CO}_{3}$ and $35 \mathrm{mM} \mathrm{NaHCO}$ ). Preparations were incubated for $16 \mathrm{~h}$ at $4^{\circ} \mathrm{C}$. The tubes were rinsed 20 times with PBS containing 0.1\% Tween-20 (PBST) and 20 times with PBS and then incubated for $1 \mathrm{~h}$ at room temperature with PBST containing 3\% nonfat milk powder (MPBST). The MPBST was removed and phage preparation $\left(10^{12} \mathrm{CFU}\right)$ added and incubated for $1 \mathrm{~h}$ at $37^{\circ} \mathrm{C}$. Tubes were rinsed as above and the remaining phage eluted by the addition of $1 \mathrm{ml}$ of $100 \mathrm{mM}$ triethylamine. The eluate was neutralized and used to infect $E$. coli strain TG-1 cells. The phagemid clones were rescued by the addition of M13KO7 helper phage and the resultant polyclonal phage preparation used in a subsequent round of selection. After three to five consecutive rounds of selection, individual colonies were grown and phage were tested for binding to PLRV.

$\mathrm{scFv}$ were expressed fused to either the human light chain kappa constant domain $\left(\mathrm{C}_{\mathrm{L}}\right)(6)$, an amphipathic helical domain (Zip) that forms stable dimers on expression in $\operatorname{E}$. coli $(9,17)$, a combination of $\mathrm{C}_{\mathrm{L}}$ plus Zip $\left(\mathrm{C}_{\mathrm{L}} \mathrm{Zip}\right)$, or a mutated form of bacterial AP that exhibits greater specific activity than the wild type (AP/S) $(3,9$, 10). Methods for expression of $s c F v$ in $\mathrm{pSKAP} / \mathrm{S}$ (3) are described in Harper et al. (5). $\mathrm{scFvC}_{\mathrm{L}}$ fusion proteins were expressed using a modified form of the expression vector pPM1-His (15), which contains a Not I restriction enzyme site instead of the XhoI site and was named $\mathrm{pC}_{\mathrm{L}}(6)$. For expression of $\mathrm{scFv}$ in $\mathrm{pC}_{\mathrm{L}}, 5 \mathrm{ml}$ of LuriaBertani (LB) broth that contained $100 \mu \mathrm{g}$ of ampicillin per $\mathrm{ml}$ and $1 \%$ glucose (wt/vol) were inoculated with a single colony of transformed $E$. coli TG- 1 cells and the culture shaken overnight at $30^{\circ} \mathrm{C}$. Next, $2 \times$ tryptone yeast extract (TY) medium $(250 \mathrm{ml})(16 \mathrm{~g}$ of bactotryptone, $10 \mathrm{~g}$ of bactoyeast extract, and $5 \mathrm{~g}$ of $\mathrm{NaCl}$ per liter) that contained $100 \mu \mathrm{g}$ of ampicillin per $\mathrm{ml}$ and $1 \%$ glucose was inoculated with $1.25 \mathrm{ml}$ of the overnight culture and shaken for approximately $4 \mathrm{~h}$ at $30^{\circ} \mathrm{C}$ and $1 \mathrm{~h}$ at $16^{\circ} \mathrm{C}$. The cells were sedimented $\left(5,000 \times g\right.$ for $10 \mathrm{~min}$ at $\left.16^{\circ} \mathrm{C}\right)$ and resuspended in $250 \mathrm{ml}$ of fresh $2 \times$ TY medium that contained $100 \mu \mathrm{g}$ of $1 \mathrm{mM}$ isopropyl- $\beta$-D-thiogalactopyranoside (IPTG) per $\mathrm{ml}$ and $1 \%$ glycerol ( $\mathrm{vol} / \mathrm{vol}$ ). It has been found that different $\mathrm{scFv}$ expressed using the

TABLE 1. Detection of potato leafroll virus (PLRV) in potato leaf extracts by triple-antibody sandwich enzyme-linked immunosorbent assay; a comparison of $11 \mathrm{scFvC}_{\mathrm{L}}$ and SCR3

\begin{tabular}{|c|c|c|}
\hline $\mathrm{scFvC}_{\mathrm{L}}$ fusion protein & Infected leaf extract & Noninfected leaf extract \\
\hline $\mathrm{V}_{1} \mathrm{C}_{\mathrm{L}}$ & 1.27 & 0.09 \\
\hline $\mathrm{V} 2 \mathrm{C}_{\mathrm{L}}$ & 1.34 & 0.09 \\
\hline $\mathrm{V} 3 \mathrm{C}_{\mathrm{L}}$ & 1.64 & 0.09 \\
\hline $\mathrm{V} 4 \mathrm{C}_{\mathrm{L}}^{\mathrm{L}}$ & 2.20 & 0.12 \\
\hline $\mathrm{V} \mathrm{C}_{\mathrm{L}}$ & 0.16 & 0.11 \\
\hline V6 $C_{L}$ & $\underline{1.81}$ & 0.09 \\
\hline $\mathrm{V} \mathrm{C}_{\mathrm{L}}$ & $\underline{0.53}$ & 0.09 \\
\hline $\mathrm{V}^{2} \mathrm{C}_{\mathrm{L}}$ & $\overline{2.55}$ & 0.11 \\
\hline $\mathrm{V} 9 \mathrm{C}_{\mathrm{L}}$ & $\overline{0.87}$ & 0.13 \\
\hline $\mathrm{N} 10 \mathrm{C}_{\mathrm{L}}$ & $\underline{0.77}$ & 0.09 \\
\hline $\mathrm{N} 11 \mathrm{C}_{\mathrm{L}}$ & 1.26 & 0.12 \\
\hline$X_{C_{L}}^{c}$ & 0.09 & 0.09 \\
\hline SCR3 & 1.08 & 0.09 \\
\hline
\end{tabular}

PLRV was trapped from potato leaf extracts using polyclonal immunoglobulin. Absorbance values $\left(A_{405 \mathrm{~nm}}\right)$ shown are the mean of duplicate wells after $2 \mathrm{~h}$ of incubation with substrate.

Underlined values represent positive reactions.

$\mathrm{XC}_{\mathrm{L}}=$ unrelated $\mathrm{scFvC}_{\mathrm{L}}$. same vector may require different expression conditions to obtain maximum yields (5). Cultures for expression of V8AP/S and all $\mathrm{scFvC}_{\mathrm{L}}$ fusion proteins were shaken for 16 to $40 \mathrm{~h}$ at $16^{\circ} \mathrm{C}$ to induce protein expression, whereas the optimum induction time for fusion protein V9AP/S was 7 days at $16^{\circ} \mathrm{C}$. Expression of scFvZip and $\mathrm{scFvC}_{\mathrm{L}}$ Zip was as follows: a single colony was inoculated into $5 \mathrm{ml}$ of LB broth that contained $100 \mu \mathrm{g}$ of ampicillin per $\mathrm{ml}$ and $2 \%$ glucose (wt/vol) and incubated at $30^{\circ} \mathrm{C}$ overnight with shaking. M9ZB medium $(250 \mathrm{ml})(10 \mathrm{~g}$ of bactotryptone, $5 \mathrm{~g}$ of bactoyeast extract, $5 \mathrm{~g}$ of $\mathrm{NaCl}, 1 \mathrm{~g}$ of $\mathrm{NH}_{4} \mathrm{Cl}, 3 \mathrm{~g}$ of $\mathrm{KH}_{2} \mathrm{PO}_{4}$, and $1 \mathrm{mM} \mathrm{MgSO}_{4}$ per liter) that contained $100 \mu \mathrm{g}$ of ampicillin per ml and $0.4 \%$ glucose was inoculated with $1.25 \mathrm{ml}$ of the overnight culture and incubated at $37^{\circ} \mathrm{C}$ with shaking for $4 \mathrm{~h}$, followed by $1 \mathrm{~h}$ at $16^{\circ} \mathrm{C}$ with shaking. The culture was centrifuged at $5,000 \times g$ for $10 \mathrm{~min}$ at room temperature, and the cell pellet was resuspended in $250 \mathrm{ml}$ of M9ZB containing ampicillin, IPTG, and glycerol at final concentrations of $100 \mu \mathrm{g} / \mathrm{ml}, 1 \mathrm{mM}$, and $2 \%$, respectively. Cultures were incubated at $16^{\circ} \mathrm{C}$ with shaking for $72 \mathrm{~h}$.

Soluble $\mathrm{scFv}$ fusion protein V8AP/S and all $\mathrm{scFvC}_{\mathrm{L}}$ were harvested from the periplasm as follows: bacterial cells were sedimented $\left(5,000 \times g\right.$ for $10 \mathrm{~min}$ at $\left.4^{\circ} \mathrm{C}\right)$ and resuspended in $1 / 20$ the original volume of $30 \%$ sucrose $(\mathrm{wt} / \mathrm{vol})$ containing $1 \mathrm{mM}$ EDTA and $50 \mathrm{mM}$ Tris- $\mathrm{HCl}, \mathrm{pH}$ 8.0. The cells were sedimented as before, resuspended in the same volume of $5 \mathrm{mM} \mathrm{MgSO}_{4}$, and kept on ice for 45 to $60 \mathrm{~min}$. Any remaining cell debris was sedimented as before and the periplasmic extract was retained.

Fusion proteins V9AP/S and all scFvZip and $\mathrm{scFvC}_{\mathrm{L}}$ Zip proteins were harvested from the culture supernatant as described in Kerschbaumer et al. (9). All of the constructs contained a hexahistidine sequence that facilitated purification from bacterial cultures by using nickel-nitrilotriacetic acid (Ni-NTA) resin (Qiagen Inc., Chatsworth, CA). The scFv were stored in PBS after buffer exchange using PD10 desalting columns (Amersham Pharmacia Biotech, St. Albans, United Kingdom). Concentrations were determined using the Bio-Rad protein assay (Bio-Rad Laboratories, Hemel Hempstead, United Kingdom) with bovine serum albumin as standard.

ELISA. Plate-trapped antigen (PTA), double-antibody sandwich (DAS)-, and triple-antibody sandwich (TAS)-ELISA were done essentially as described by Torrance (24). ELISAs were repeated at least three times. Data presented are values obtained from a typical experiment.

Tests to detect PLRV in plant extracts. ELISA plate wells (MaxiSorp; Nalge Nunc International) were coated per well with $100 \mu 1$

TABLE 2. Absorbance values obtained from triple-antibody sandwich enzymelinked immunosorbent assays to determine the cross-reactivity of $\mathrm{scFv}$ fusion proteins with four luteoviruses

\begin{tabular}{lcccc}
\hline & \multicolumn{4}{c}{ Virus $^{\mathrm{a}, \mathrm{b}}$} \\
\cline { 2 - 5 } Detecting reagent & BWYV & BMYV & CYDV-RPV & GRAV \\
\hline Positive control MAb & $\underline{2.5 / 0.1}$ & $\underline{1.4 / 0.1}$ & $\underline{0.4 / 0.1}$ & $\underline{2.3 / 0.1}$ \\
N10C & $\underline{0.7 / 0.2}$ & $\underline{0.6 / 0.2}$ & $0.2 / 0.1$ & $0.3 / 0.2$ \\
N11C $_{\mathrm{L}}$ & $\underline{1.7 / 0.3}$ & $\underline{1.3 / 0.3}$ & $\underline{0.3 / 0.1}$ & $\underline{0.7 / 0.3}$ \\
V1C $_{\mathrm{L}}$ & $0.3 / 0.2$ & $0.3 / 0.3$ & $0.1 / 0.1$ & $0.2 / 0.2$ \\
V2C $_{\mathrm{L}}$ & $0.2 / 0.3$ & $0.2 / 0.3$ & $0.2 / 0.1$ & $0.2 / 0.2$ \\
V3C $_{\mathrm{L}}$ & $0.2 / 0.2$ & $0.2 / 0.3$ & $0.1 / 0.1$ & $0.2 / 0.2$ \\
V4C $_{\mathrm{L}}$ & $0.3 / 0.2$ & $0.3 / 0.3$ & $0.1 / 0.1$ & $0.3 / 0.2$ \\
V5C $_{\mathrm{L}}$ & $0.3 / 0.2$ & $0.3 / 0.3$ & $0.1 / 0.1$ & $0.2 / 0.2$ \\
V6C $_{\mathrm{L}}$ & $0.2 / 0.2$ & $0.3 / 0.3$ & $0.1 / 0.1$ & $0.2 / 0.2$ \\
V7C $_{\mathrm{L}}$ & $0.1 / 0.1$ & $0.3 / 0.3$ & $0.1 / 0.1$ & $0.1 / 0.1$ \\
V8C $_{\mathrm{L}}$ & $\underline{2.8 / 0.3}$ & $\underline{2.5 / 0.3}$ & $\underline{0.9 / 0.2}$ & $\underline{1.7 / 0.3}$ \\
V9C $_{\mathrm{L}}$ & $\underline{0.5 / 0.2}$ & $\underline{0.7 / 0.3}$ & $0.1 / 0.1$ & $0.2 / 0.2$ \\
\hline
\end{tabular}

Viruses were trapped using a polyclonal immunoglobulin preparation known to react with each virus. BWYV = beet western yellows virus, BMYV = beet mild yellowing virus, CYDV-RPV = cereal yellow dwarf virus-RPV, and GRAV = groundnut rosette assistor virus. Absorbance values $\left(A_{405 \mathrm{~nm}}\right)$ given are the mean of duplicate wells after overnight incubation with substrate. The first value is that obtained from infected leaf extracts, the second is that obtained from noninfected leaf extracts.

Underlined values represent positive reactions. 
of an anti-PLRV immunoglobulin preparation from a rabbit polyclonal antiserum (polyclonal Ig) (22) at $1 \mu \mathrm{g} / \mathrm{ml}$ diluted in carbonate coating buffer and incubated overnight at $4^{\circ} \mathrm{C}$. After washing with PBS, wells were blocked with 3\% (wt/vol) low-fat milk powder (Marvel; Premier Beverages, Adbaston, United Kingdom) in PBS (PBSM). Extracts of noninfected or infected potato (Solanum tuberosum cv. Maris Piper) leaves were prepared by crushing $1 \mathrm{~g}$ of leaf tissue in $5 \mathrm{ml}$ of extraction buffer (1\% polyvinylpyrrolidone and $0.05 \%$ Tween-20 in PBS). Plant extract (100 $\mu \mathrm{l} /$ well) was added to ELISA plates and incubated overnight at $4^{\circ} \mathrm{C}$. The plates were washed with PBST three times and then with PBS three times. Purified preparations of $\mathrm{scFv}$ fusion proteins were added after dilution in PBSM by $1: 100\left(\mathrm{scFvC}_{\mathrm{L}}, \mathrm{scFvZip}\right.$, and $\left.\mathrm{scFvC}_{\mathrm{L}} \mathrm{Zip}\right)$ or $1: 10$ (scFvAP/S). $\mathrm{scFvC}_{\mathrm{L}}$ and $\mathrm{scFvC}_{\mathrm{L}} \mathrm{Zip}$ fusion proteins were added to the wells in a mixture with an anti-human kappa domain antibody conjugated to AP (anti-kappa AP conjugate A-3813; Sigma Chemical Co., St. Louis) diluted 1:5,000. scFvZip fusion proteins were added to wells in a mixture with an anti-histidine antibody $(\mathrm{H}-$ 1029; Sigma Chemical Co.) diluted 1:2,000 and an anti-mouse AP conjugate (anti-mouse AP conjugate A-1902; Sigma Chemical Co.) diluted 1:1,000. A preparation of anti-PLRV MAb SCR3 (11) was diluted 1:1,000 (to $1 \mu \mathrm{g} / \mathrm{ml}$ ) before use and incubated in a mixture with anti-mouse AP conjugate diluted 1:1,000. scFv fusion proteins and SCR3 were incubated for $2 \mathrm{~h}$ at $30^{\circ} \mathrm{C}$. The enzyme substrate was $p$-nitrophenyl phosphate, $1 \mathrm{mg} / \mathrm{ml}$ of $10 \%$ diethanolamine buffer, $\mathrm{pH}$ 9.8. The absorbance at $405 \mathrm{~nm}\left(A_{405 \mathrm{~nm}}\right)$ was measured using a Titertek Multiskan PLUS photometer (Titertek, Huntsville, AL) after 2 and $16 \mathrm{~h}$ at room temperature (approximately $22^{\circ} \mathrm{C}$ ). Values were considered positive if they exceeded the mean of the negative control by a factor of two.

Tests to detect cross-reactions with other luteoviruses. Cross-reactivities of $\mathrm{scFvC}_{\mathrm{L}}$ fusion proteins were measured by TAS-ELISA as described above, except that the plates were coated with polyclonal Ig preparations known to react with each of the luteoviruses tested. Extracts from noninfected or infected leaves were prepared as above. A MAb known to react with each virus was used as a positive control, and an unrelated $\mathrm{scFvC}_{\mathrm{L}}$ protein was used as a negative control.

Groundnut rosette assistor virus (GRAV)-infected groundnut leaf material and GRAV-specific polyclonal Ig were obtained from D. J. Robinson, Scottish Crop Research Intitute. Anti-PLRV MAb SCR6 (11) was used for the detection of GRAV. Barley leaf material infected with cereal yellow dwarf virus-RPV (CYDV-RPV) was provided by J. North and I. Barker, Central Science Laboratory, York. Anti-CYDV polyclonal Ig and the MAb MAC92 (25) were used for trapping and detecting CYDV-RPV, respectively. $\mathrm{H}$. Smith, Institute of Arable Crops Research (IACR)-Broom's Barn, Bury St. Edmunds, provided oil seed rape leaf material infected with beet western yellows virus (BWYV) and sugar beet leaves infected with beet mild yellowing virus (BMYV). An anti-BWYV polyclonal Ig obtained from R. R. Martin (Horticulture Crops Research Laboratory, Corvallis, OR) was used to trap both BWYV and BMYV. BWYV was detected with the BWYV MAb $510 \mathrm{H}$ provided by P. Ellis and R. R. Martin (2), and BMYV was detected with the MAb PAV-IL-1 provided by H. Smith, originally obtained from C. J. D'Arcy (2).

PTA-ELISA for potato virus $Y(P V Y)$ and purified PLRV. PTAELISA for PVY was done by coating the wells of ELISA plates with $100 \mu \mathrm{l}$ of extracts $(0.2 \mathrm{~g} / \mathrm{ml})$ of PVY-infected Nicotiana debneyi leaves for $16 \mathrm{~h}$ at $4^{\circ} \mathrm{C}$. Plates were rinsed and the ELISA completed by the addition of $\mathrm{scFv}$ fusion proteins or anti-PVY polyclonal Ig and an appropriate enzyme conjugate as described above.

PLRV was purified as described by Mayo et al. (12). Virus particles were suspended in PBS at concentrations from 1 to $750 \mathrm{ng} / \mathrm{ml}$. PLRV particles diluted in PBS were added to the wells of a microtiter plate $\left(100 \mu \mathrm{l}\right.$ per well) and incubated at $4^{\circ} \mathrm{C}$ overnight, and the ELISA was completed as described above. Limits of detection were recorded as the PLRV concentration below which the mean absor- bance value was less than twice the mean of the negative control, after $2 \mathrm{~h}$ of incubation with substrate, from three separate assays.

$s c F v$ fusion proteins as coating reagents. scFv fusion proteins were diluted to $1 \mu \mathrm{g} / \mathrm{ml}$ in PBS, added to a microtiter plate $(100 \mu \mathrm{l}$ per well), and incubated at $4^{\circ} \mathrm{C}$ overnight. The assay was completed as described above, except that leaves were extracted in PBS containing $1 \%$ polyvinylpyrrolidone plus $0.5 \%$ Tween- 20 .

Stem printing. Stem printing was done essentially as described by Cassab and Varner (1) and Polston et al. (18). Prints were prepared by pressing freshly cut noninfected or infected potato stems onto nitrocellulose membrane (protran BA83 Cellulose-nitrate; Schleicher \& Schuell, Inc., Keene, NH). After drying, the membranes were used immediately or stored at room temperature. The printed membranes were incubated in blocking buffer, 5\% low-fat milk powder (Marvel) in TBS (TBSM; $10 \mathrm{mM}$ Tris $\mathrm{HCl}$ and $0.9 \%$ $\mathrm{NaCl}, \mathrm{pH} 7.4$ ), for $1 \mathrm{~h}$ at room temperature with gentle shaking. The stem prints were incubated with the detecting antibodies diluted in TBSM for $2 \mathrm{~h}$ at room temperature with gentle shaking. SCR3

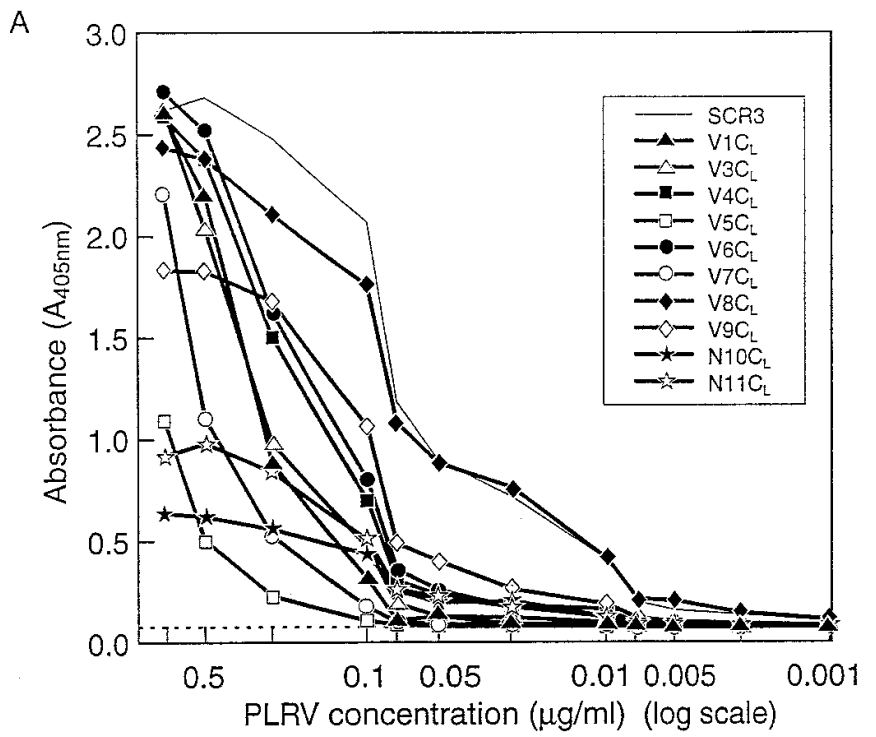

B

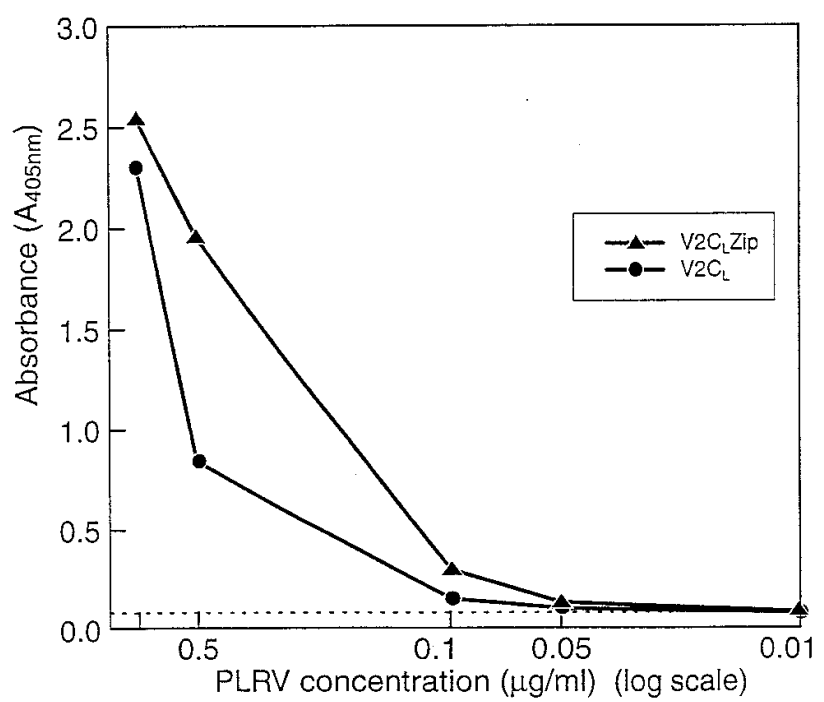

Fig. 1. Plate-trapped antigen enzyme-linked immunosorbent assay to determine the limits of detection of potato leafroll virus (PLRV) by scFv fusion proteins compared with monoclonal antibody (MAb) SCR3. Purified PLRV at different concentrations were coated onto microtiter plates. Absorbance values $\left(A_{405 \mathrm{~nm}}\right)$ were obtained after $2 \mathrm{~h}$ of incubation with substrate. The mean $A_{405 \mathrm{~nm}}$ value (values ranged from 0.071 to 0.087 ) obtained when phosphate-buffered saline was coated onto microtiter plates is shown as a dotted line. A, Comparison of $10 \mathrm{scFv} \mathrm{C}_{\mathrm{L}}$ fusion proteins with the MAb SCR3; and $\mathbf{B}$, comparison of $\mathrm{V}_{2} \mathrm{C}_{\mathrm{L}}$ with $\mathrm{V} 2 \mathrm{C}_{\mathrm{L}} \mathrm{Zip}$. 
and anti-mouse AP conjugate were both diluted to 1:1,000, and $\mathrm{scFvC}_{\mathrm{L}}$ and anti-kappa AP conjugate were diluted 1:100 and 1:5,000, respectively. scFvAP/S fusion protein was diluted 1:10. After washing membranes three times for $5 \mathrm{~min}$ each in TBS containing $0.05 \%$ Tween-20 and three times with TBS, nitro blue tetrazolium-5-bromo4-chloro-3-indolyl phosphate (Sigma Chemical Co.) substrate was added for 3 to $5 \mathrm{~min}$. After washing with water, the green color of the stem prints was removed by placing each print into $1 \%$ sodium hypochlorite solution for 3 to $5 \mathrm{~min}$ and then washing with water. After drying, the prints were observed under low-power magnification $(\times 10$ to $\times 20)$ with a Kyowa light microscope (Kyowa, Tokyo) and photographed with a Nikon FE2 camera (Nikon Corp., Tokyo).

Storage of $\mathbf{s c F v}$ fusion proteins. $\mathrm{scFv}$ fusion proteins were purified as described above and treated as follows: (i) addition of $0.05 \%$ sodium azide and storage at $4{ }^{\circ} \mathrm{C}$; (ii) addition of $0.05 \%$ sodium azide and ethylene glycol (final concentration 33\%; Pierce \& Warriner, Chester, United Kingdom) and storage at $-20^{\circ} \mathrm{C}$; and (iii) storage under vacuum at $-20^{\circ} \mathrm{C}$ after lyophilization using an Edwards High Vacuum Modulyo freeze dryer, spin freezer, and pump (Merck Ltd., Poole, United Kingdom). The stored samples were tested at intervals by ELISA as described above.

\section{RESULTS}

Detection of PLRV using scFv fusion proteins in ELISA. For each $\mathrm{scFv}$ fusion protein, a dilution series of a purified preparation was made and each dilution was used (100 $\mu \mathrm{l}$ per well) in a TAS-
ELISA to detect PLRV from extracts of infected potato leaves. From the resulting titration curves, a dilution of 1:100 was selected for $\mathrm{scFvC}_{\mathrm{L}}, \mathrm{scFvZip}$, and $\mathrm{scFvC}_{\mathrm{L}} \mathrm{Zip}$, and $1: 10$ for $\mathrm{scFvAP} / \mathrm{S}$ for routine use, because the activity for each $\mathrm{scFv}$ fusion protein was saturated at these dilutions (data not shown). Purified $s c F v$ fusion protein preparations contained approximately 100 to $500 \mu \mathrm{g} / \mathrm{ml}$, so that $\mathrm{scFvC}_{\mathrm{L}}, \mathrm{scFvZip}$, and $\mathrm{scFvC}_{\mathrm{L}}$ Zip proteins were used at approximately 1 to $5 \mu \mathrm{g} / \mathrm{ml}$ in ELISA, and scFvAP/S at approximately 10 to $50 \mu \mathrm{g} / \mathrm{ml}$.

$\mathrm{ScFvC}_{\mathrm{L}}$ fusion proteins were used in ELISA to detect PLRV in extracts of leaves of potato (cv. Maris Piper). A typical result is shown in Table 1 . In these tests, the $A_{405 \mathrm{~nm}}$ values obtained with $\mathrm{V} 1 \mathrm{C}_{\mathrm{L}}, \mathrm{V} 2 \mathrm{C}_{\mathrm{L}}, \mathrm{V} 3 \mathrm{C}_{\mathrm{L}}, \mathrm{V} 4 \mathrm{C}_{\mathrm{L}}, \mathrm{V} 6 \mathrm{C}_{\mathrm{L}}, \mathrm{V} 8 \mathrm{C}_{\mathrm{L}}$, and $\mathrm{N} 11 \mathrm{C}_{\mathrm{L}}$ were consistently equal to, or greater than, those obtained with SCR3.

AP fusions of scFv clones V7, V8, and V9 readily detected PLRV in potato leaf extracts. In a typical experiment, $A_{405 \mathrm{~nm}}$ values of 0.85 , 0.58 , and 0.49 for $\mathrm{V} 9 \mathrm{AP} / \mathrm{S}, \mathrm{V7AP} / \mathrm{S}$, and $\mathrm{V} 8 \mathrm{AP} / \mathrm{S}$, respectively, were obtained compared with a value of 0.86 for SCR3. V9AP/S consistently gave the best result of the three scFvAP/S fusions.

Cross-reactivities of scFv. There is extensive amino acid identity among the sequences of luteovirus coat proteins (13), and many antisera raised to luteoviruses cross-react $(19,23)$. Tests were done to ascertain whether scFv that bind PLRV cross-react with other luteoviruses. Leaf extracts from plants infected with GRAV, CYDVRPV, BWYV, or BMYV were tested by TAS-ELISA using the $\mathrm{scFvC}_{\mathrm{L}}$ fusion proteins. Results from typical assays are given in Table 2. Of the two clones selected against dissociated PLRV par-

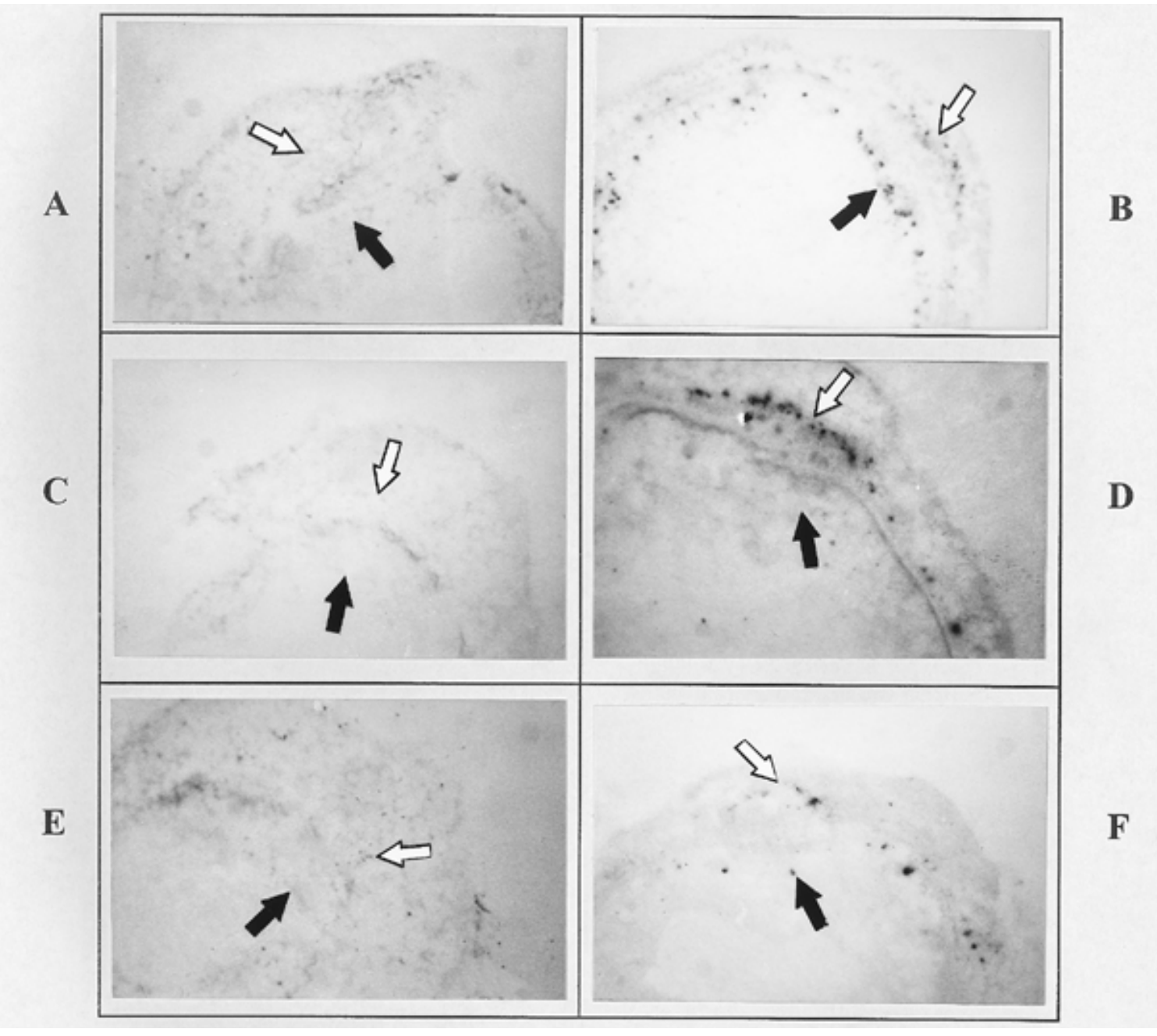

Fig. 2. Detection of potato leafroll virus (PLRV) in stem prints by $\mathrm{scFvC}_{\mathrm{L}}$ and $\mathrm{scFvAP/S}$ fusion proteins. A, Noninfected stem print, SCR3; B, infected stem print, SCR3; C, noninfected stem print, ${\mathrm{V} 3 \mathrm{C}_{\mathrm{L}}}_{\mathbf{1}} \mathbf{D}$, infected stem print, $\mathrm{V}_{\mathrm{L}} \mathrm{C}_{\mathrm{L}} ; \mathbf{E}$, noninfected stem print, $\mathrm{V} 7 \mathrm{AP} / \mathrm{S}$; and $\mathbf{F}$, infected stem print, V7AP/S. Black spots in the vascular area of sections of plant stems indicate the presence of PLRV. Black and white arrows indicate position of internal and external phloem, respectively. Magnification of $\times 13$, except $\mathbf{D}(\times 20)$. 
ticles, $\mathrm{V} 8 \mathrm{C}_{\mathrm{L}}$ bound to all four viruses to give $A_{405 \mathrm{~nm}}$ values similar to those obtained with the control MAbs, whereas $\mathrm{V} \mathrm{C}_{\mathrm{L}}$ showed heterologous reactions with BWYV and BMYV, but not with CYDV-RPV or GRAV. N11C $\mathrm{C}_{\mathrm{L}}$ bound all four luteoviruses tested, and clone $\mathrm{N}_{10 \mathrm{C}_{\mathrm{L}}}$ bound BWYV and BMYV, but not CYDV-RPV or GRAV. In contrast, none of the scFV selected from the "nonimmunized" scFv library against PLRV particles (V1 to V7) bound to the other luteoviruses tested (Table 2). No reaction was obtained when $\mathrm{V} 8 \mathrm{C}_{\mathrm{L}}, \mathrm{V} 9 \mathrm{C}_{\mathrm{L}}$, or $\mathrm{V} 3 \mathrm{C}_{\mathrm{L}}$ were used in an ELISA to detect PVY (family Potyviridae). Mean $A_{405 \mathrm{~nm}}$ values of 0.30 and 2.60 were obtained with the anti-PVY polyclonal Ig against noninfected and infected extracts, respectively, compared with 0.07 and 0.07 with each of the $\mathrm{scFvC}_{\mathrm{L}}$ preparations after $16 \mathrm{~h}$ of incubation with substrate.

Detection limits of $\mathbf{s c F v}$ fusion proteins. $\mathrm{scFv}$ fusion proteins were used in PTA-ELISA to detect purified PLRV. A typical result after $2 \mathrm{~h}$ of incubation with substrate is shown in Figure 1. At a PLRV concentration of $0.75 \mu \mathrm{g} / \mathrm{ml}, 7$ of the $11 \mathrm{scFvC}_{\mathrm{L}}$ proteins gave $A_{405 \mathrm{~nm}}$ values similar to those of the MAb SCR3 (Fig. 1A). The detection limit for SCR3 was $5 \mathrm{ng} / \mathrm{ml}$, and one of the $\mathrm{scFvC}_{\mathrm{L}}$

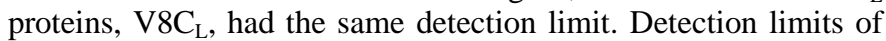
the remaining $\mathrm{scFv}$ fusion proteins ranged from $250 \mathrm{ng} / \mathrm{ml}$ for $\mathrm{V}_{5} \mathrm{C}_{\mathrm{L}}$ to $10 \mathrm{ng} / \mathrm{ml}$ for $\mathrm{V}_{9} \mathrm{C}_{\mathrm{L}}$. The overall ranking for detection limit for $\mathrm{scFvC}_{\mathrm{L}}$ was $\mathrm{V} 8=\mathrm{SCR} 3>\mathrm{V} 9=\mathrm{V} 4=\mathrm{V} 6=\mathrm{N} 10=\mathrm{N} 11>\mathrm{V} 3=$ $\mathrm{V} 1=\mathrm{V} 2=\mathrm{V} 7>\mathrm{V} 5$.

$\mathrm{V} 2 \mathrm{C}_{\mathrm{L}}$ Zip consistently gave greater $A_{405 \mathrm{~nm}}$ values than did $\mathrm{V} 2 \mathrm{C}_{\mathrm{L}}$ in PTA-ELISA over a range of PLRV concentrations, suggesting that the presence of the amphipathic helical domain confers bivalent binding and, therefore, greater avidity on the $\mathrm{scFv}$. A representative titration is shown in Figure 1B. The limit of detection for $\mathrm{V}_{2} \mathrm{C}_{\mathrm{L}}$ Zip was between 50 and $100 \mathrm{ng} / \mathrm{ml}$ compared with approxi-

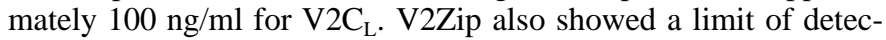
tion of between 50 and $100 \mathrm{ng} / \mathrm{ml}$ when detected using an antihistidine antibody (data not shown).

Stem printing. PLRV was detected in prints of infected potato stems pressed onto nitrocellulose membrane when these were reacted with $\mathrm{V} 3 \mathrm{C}_{\mathrm{L}}$ or $\mathrm{V} 7 \mathrm{AP} / \mathrm{S}$ (Fig. 2) or with $\mathrm{V} 6 \mathrm{C}_{\mathrm{L}}$ or $\mathrm{V} 8 \mathrm{C}_{\mathrm{L}}$ (data not shown). Staining was evident in the vascular bundles of infected stems, but not in the prints of noninfected stems. The results obtained by using $\mathrm{scFvC}_{\mathrm{L}}$ or $\mathrm{scFvAP} / \mathrm{S}$ were similar to those obtained with SCR3.

Storage of scFv fusion proteins. For detection reagents to be of practical value, they must be stable and retain activity during storage for extended periods. $\mathrm{scFv}$ fusion proteins were tested for their ability to detect PLRV in potato leaf extracts after storage in different conditions. Purified $\mathrm{scFvC}_{\mathrm{L}}$ fusion proteins (V1 to V6) were stored at $4{ }^{\circ} \mathrm{C}$ in PBS that contained $0.05 \%$ sodium azide for at least 6 months without loss of activity in ELISA. For example, freshly made $\mathrm{V}_{4} \mathrm{C}_{\mathrm{L}}$ gave an $A_{405 \mathrm{~nm}}$ value of 2.1 in an ELISA to detect PLRV in potato plant extract compared with a value of 0.99 for SCR3, after $2 \mathrm{~h}$ of incubation with substrate. After 6 months of storage at $4^{\circ} \mathrm{C}$, the same preparation gave an $A_{405 \mathrm{~nm}}$ value of $2.4 \mathrm{in}$ a similar ELISA compared with a value of 1.53 for SCR3. Purified $\mathrm{V} \mathrm{C}_{\mathrm{L}}, \mathrm{V} \mathrm{C}_{\mathrm{L}}$, and several different $\mathrm{scFvC}_{\mathrm{L}}$ Zip fusion proteins were stored in the same way for up to 1 month. However, $\mathrm{C}_{\mathrm{L}} \mathrm{Zip}$ fusion proteins that were stored for longer than 1 month gave high nonspecific background reactions. Purified scFvAP/S could only be stored for 1 to 2 days at $4^{\circ} \mathrm{C}$, after which all activity in ELISA was lost. For example, a purified preparation of V8AP/S used after storage for 2 days at $4^{\circ} \mathrm{C}$ gave a value of 0.37 in an ELISA to detect PLRV in potato leaf extracts, after $2 \mathrm{~h}$ of incubation with substrate. After a further 5 days of storage at $4^{\circ} \mathrm{C}$, the same preparation gave a value of 0.02 in a similar ELISA in which the $A_{405 \mathrm{~nm}}$ value for the SCR3 control was approximately 1.0. However, when $\mathrm{scFvAP} / \mathrm{S}$ and $\mathrm{scFvC}_{\mathrm{L}}$ were lyophilized and stored for 18 months, they were still functional on reconstitution. Three out of six different purified proteins stored at $-20^{\circ} \mathrm{C}$ with ethylene glycol lost approximately half of their activity after 1 month com- pared with the same type of antibody preparation stored at $4{ }^{\circ} \mathrm{C}$ in PBS with $0.05 \%$ sodium azide.

scFv fusion proteins for coating ELISA plates. $s c F v V 1 C_{L}$ to $\mathrm{V}_{6} \mathrm{C}_{\mathrm{L}}$ retained activity when used (at approximately $0.1 \mu \mathrm{g}$ per well) to coat ELISA plates, successfully trapping purified PLRV particles or PLRV from potato leaf extracts in a TAS-ELISA (PLRV was detected using SCR3). $A_{405 \mathrm{~nm}}$ values of 0.6 to 0.8 were obtained with $\mathrm{V}_{2} \mathrm{C}_{\mathrm{L}}$ and $\mathrm{V} 3 \mathrm{C}_{\mathrm{L}}$, which were similar to that of polyclonal Ig used to coat plates at the same concentration. Using $\mathrm{V}_{1} \mathrm{C}_{\mathrm{L}}$ or $\mathrm{V} 4 \mathrm{C}_{\mathrm{L}}$ to coat plates gave $A_{405 \mathrm{~nm}}$ values of between 0.2 and 0.3 , and $\mathrm{V} \mathrm{C}_{\mathrm{L}}$ and $\mathrm{V}_{6} \mathrm{C}_{\mathrm{L}}$ gave $A_{405 \mathrm{~mm}}$ values of less than 0.2 . In contrast, $\mathrm{scFv} \mathrm{V} 8$ and V9 (selected against dissociated PLRV particles) did not trap PLRV from leaf extracts when used either as $\mathrm{scFvC}_{\mathrm{L}}$ or as $\mathrm{scFvC}_{\mathrm{L}}$ Zip fusions. These fusion proteins did trap purified PLRV particles, although the addition of noninfected leaf extract to the purified PLRV preparation inhibited the trapping (data not shown).

scFv selected against PLRV particles could also act as coating reagents when used as $\mathrm{scFvC}_{\mathrm{L}} \mathrm{Zip}$ fusions. In a typical experiment,

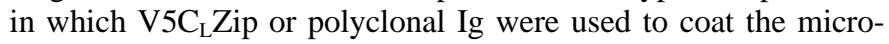
titer plate, and PLRV from potato leaf extracts was detected using SCR3, coating with $\mathrm{V}_{5} \mathrm{C}_{\mathrm{L}}$ Zip resulted in higher $A_{405 \mathrm{~nm}}$ values than did coating with the polyclonal $\mathrm{Ig}$; values were 0.83 and 0.55 , respectively. Coating with $\mathrm{V} 2 \mathrm{C}_{\mathrm{L}} \mathrm{Zip}, \mathrm{V} 4 \mathrm{C}_{\mathrm{L}} \mathrm{Zip}$, and $\mathrm{V} 6 \mathrm{C}_{\mathrm{L}}$ Zip gave $A_{405 \mathrm{~nm}}$ values of $0.39,0.43$, and 0.58 , respectively, in the same experiment.

Of four fusion proteins tested, only scFv V2 could trap PLRV when expressed as a scFvZip fusion. Several different $s c F v$ fusion proteins were used to detect PLRV trapped by V2Zip. Detection with $\mathrm{V}_{4} \mathrm{C}_{\mathrm{L}}$ or $\mathrm{V} 6 \mathrm{C}_{\mathrm{L}}$ gave $A_{405 \mathrm{~nm}}$ values of 2.0 to 2.5 , similar to those obtained in tests in which PLRV was trapped by polyclonal $\mathrm{Ig}$ and detected by SCR3. Detection with $\mathrm{V}_{\mathrm{C}}, \mathrm{V}_{\mathrm{L}} \mathrm{C}_{\mathrm{L}}$, or SCR3 in the same ELISA gave $A_{405 \mathrm{~nm}}$ values of approximately 0.8 .

Fully recombinant ELISA for detection of PLRV in potato. By combining trapping with $\mathrm{V} 2 \mathrm{C}_{\mathrm{L}}, \mathrm{V} 3 \mathrm{C}_{\mathrm{L}}$, and $\mathrm{V} 2 \mathrm{C}_{\mathrm{L}}$ Zip fusion proteins with detection by $\mathrm{scFvAP} / \mathrm{S}$ fusion proteins, it was possible to devise a fully recombinant ELISA. Several combinations of $\mathrm{scFv}$ fusion proteins were tested for trapping and detecting. The best result was obtained when either $\mathrm{scFv}$ V8AP/S or V9AP/S were used

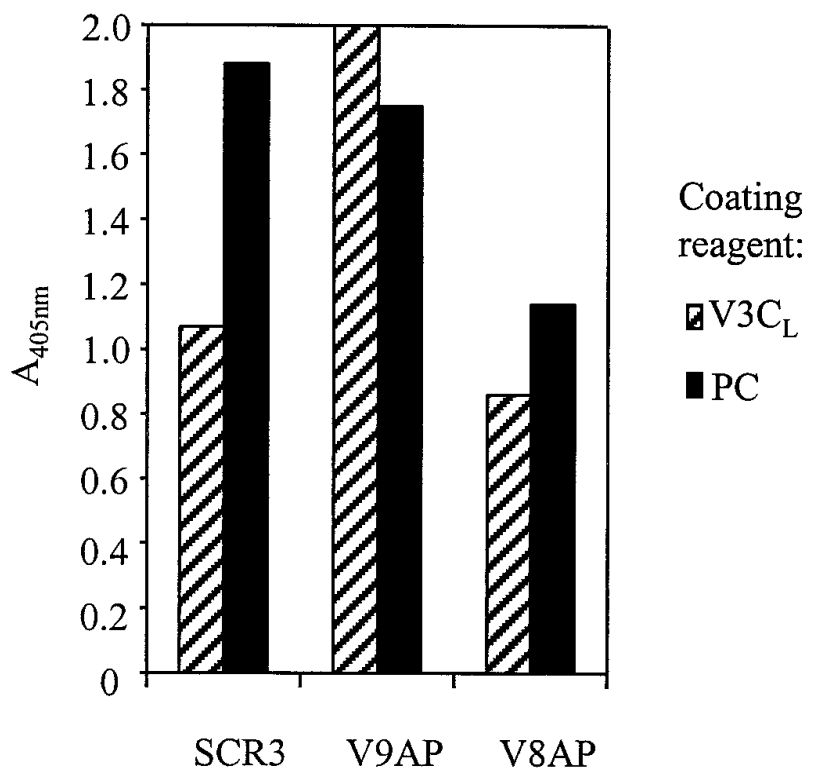

Detecting reagent

Fig. 3. Fully recombinant enzyme-linked immunosorbent assay to show trapping of potato leafroll virus in potato leaf extracts by $\mathrm{V}_{3} \mathrm{C}_{\mathrm{L}}$ and detection with scFvAP/S. Absorbance values $\left(A_{405 \mathrm{~nm}}\right)$ were obtained after $2 \mathrm{~h}$ of incubation with substrate and are presented after subtraction of noninfected control values. 


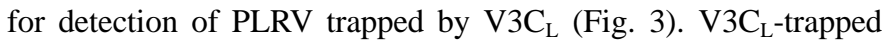
PLRV was detected with V9AP/S with an $A_{405 \mathrm{~nm}}$ value similar to that obtained using the polyclonal and monoclonal reagents.

\section{DISCUSSION}

Eleven $\mathrm{scFv}$ fusion proteins were compared with the MAb SCR3 and a polyclonal Ig preparation for effectiveness in detection or trapping of PLRV in order to assess their potential for use as practical alternatives to conventional antibodies. Of the $11 \mathrm{scFvC}_{\mathrm{L}}$ fusion proteins, 7 gave similar $A_{405 \mathrm{~nm}}$ values to the currently used MAb SCR3 when used as detecting antibodies in an ELISA to detect PLRV in extracts of infected potato leaves. scFvAP/S fusion proteins also reacted well in ELISA to detect PLRV, with one (V9AP/S) giving similar results to SCR3. In PTA-ELISA, the scFv fusion proteins displayed different sensitivities (i.e., change in $A_{405 \mathrm{~nm}}$ value with decreased PLRV concentration). For instance, $\mathrm{N} 10 \mathrm{C}_{\mathrm{L}}$ and $\mathrm{N}_{11} \mathrm{C}_{\mathrm{L}}$ have low detection limits of approximately $25 \mathrm{ng} / \mathrm{ml}$, but are not as sensitive as $\mathrm{V}_{1} \mathrm{C}_{\mathrm{L}}$ or $\mathrm{V} \mathrm{C}_{\mathrm{L}}$, which are more sensitive but have higher detection limits of approximately $100 \mathrm{ng} / \mathrm{ml}$ (Fig. 1A). One $\mathrm{scFv}$ fusion protein, $\mathrm{V}_{\mathrm{C}} \mathrm{C}_{\mathrm{L}}$, had the same limit of detection of purified PLRV as SCR3. Four scFv fusion proteins were tested in a tissue print assay and the results were the same as with SCR3, in that PLRV was clearly detected in the vascular area of sections of stems from infected potato plants. This result shows that stem printing with recombinant antibody fusion proteins is feasible as a method of detecting PLRV in potato tissues.

scFv clones (V1 to V7) did not cross-react with four other luteoviruses. In contrast, scFv clones V8, V9, N10, and N11 did crossreact with some or all of the luteoviruses tested. Also, $\mathrm{scFv}$ clones V8, V9, N10, and N11 have been shown to detect sodium dodecyl sulfate (SDS)-denatured PLRV protein in an immunoblot and to detect PLRV treated with carbonate buffer in PTA-ELISA, whereas V1 to V6 do not (6). These results indicate that the scFv from clones V8, V9, N10, and N11 are directed against continuous epitopes that are present on the coat proteins of certain related luteoviruses. In contrast, $\mathrm{scFv}$ clones $\mathrm{V} 1$ to V6 bind to discontinuous or conformation-dependent epitopes that are specific to PLRV and are disrupted by treatment with carbonate buffer or SDS.

Kerschbaumer et al. (9) demonstrated the use of a single scFvZip fusion protein, derived from an existing $\mathrm{MAb}$, as a trapping reagent for particles of beet necrotic yellow vein virus (BNYVV) from infected Tetragonia expansa indicator plants. Here, we show that $\mathrm{scFv}$ proteins selected using phage display libraries against intact PLRV particles trapped PLRV from infected potato plants on ELISA plates when expressed as fusions with $\mathrm{C}_{\mathrm{L}}$ or $\mathrm{C}_{\mathrm{L}} \mathrm{Zip}$, and one of four $\mathrm{scFv}$ proteins tested could trap PLRV when expressed as a Zip fusion. Some scFv fusions could trap PLRV as effectively as a polyclonal Ig preparation. $\mathrm{scF} v$ selected against dissociated PLRV and expressed as fusion proteins with $\mathrm{C}_{\mathrm{L}}$ or $\mathrm{C}_{\mathrm{L}} \mathrm{Zip}$ did not trap PLRV from leaf extracts, being inhibited by components of plant extract. The presence of the Zip domain in the V2 fusion protein did not markedly increase its ability to trap PLRV. However, scFv V5 is relatively poor at detecting PLRV in ELISA (Fig. 1) and at trapping PLRV as a $\mathrm{C}_{\mathrm{L}}$ fusion, but it is particularly good at trapping PLRV when expressed as a $\mathrm{C}_{\mathrm{L}} \mathrm{Zip}$ fusion. Thus, $\mathrm{scFv}$ clones that show the greatest activity in ELISA when used for detecting PLRV are not necessarily those that are most effective when used for trapping PLRV on ELISA plates, and vice versa. Also, any increase in activity brought about by expression with other fusion proteins, such as the Zip domain, may depend on the particular scFv sequence. These results demonstrate that, as with MAbs, when seeking useful reagents for diagnostic use, it is advisable to prepare a panel of $\mathrm{scFv}$ fusion proteins from which to select for a particular application. Moreover, we have found that $\mathrm{scFv}$ with different properties were obtained by selection against different kinds of virus preparations. A fully recombinant ELISA has been devised in which PLRV is trapped by $\mathrm{scFvC}_{\mathrm{L}}$ and detected by $\mathrm{scFvAP/S}$. This test works as well as a currently used test that employs antibody reagents produced from immunized animals.

The $\mathrm{scFvC}_{\mathrm{L}}$ fusion proteins were stable for at least 6 months at $4{ }^{\circ} \mathrm{C}$ in PBS with sodium azide, and they could be stored for prolonged periods (at least 18 months) by lyophilization. scFvAP/S fusion proteins stored in PBS were unstable at $4^{\circ} \mathrm{C}$, losing most activity in ELISA within a few weeks, but they can be lyophilized and stored for several months without loss of activity. However, the need to rehydrate scFvAP/S preparations for each assay is not ideal for day-to-day routine use, and further work may be required to find an improved method of storage for these reagents.

Previous studies have shown that $\mathrm{scFv}$ that bind to the plant viruses black currant reversion associated virus (21), cucumber mosaic cucumovirus (27), and PLRV (4) can be obtained from a semisynthetic phage display library. However, results of tests using these $\mathrm{scFv}$ were not as good as those using antibodies produced by immunization. The scFvAP fusion protein previously described (4) employed an unmutated form of AP and detected PLRV in leaf extracts from Physalis floridana. However, PLRV was detected only after overnight incubation with substrate, which compared poorly with a polyclonal antibody preparation. In this article, it is shown that conversion of $\mathrm{scFv}$ derived from phage display libraries to fusion proteins, particularly $\mathrm{scFvC}_{\mathrm{L}}$ and $\mathrm{scFv}$ fused to a mutated form of AP with an increased specific activity (10), produced reagents that had activities in ELISA similar to antibodies produced by immunization. Moreover, these reagents were combined in a fully recombinant ELISA to detect virus in naturally infected host plants. The properties of the panel of $\mathrm{scFv}$ fusion proteins show that libraryderived recombinant antibody fragments can provide alternative reagents for the diagnosis of PLRV infection in potatoes. Routine testing for plant virus infection by fully recombinant ELISA has a number of advantages over conventional ELISA. scFv fusion proteins can be produced quickly and cheaply and can be stored indefinitely as DNA. Furthermore, pure, well-characterized preparations of $\mathrm{scFv}$ fusion proteins provide an opportunity to devise standardized tests for use in laboratories in different countries.

\section{ACKNOWLEDGMENTS}

This work was funded by the Scottish Office Agriculture, Environment and Fisheries Department and the European Commission, contract number AIR3-CT94-1046. We thank all donors of infected leaf material, polyclonal immunoglobulin preparations, and monoclonl antibodies; Cambridge Antibody Technology for providing the "nonimmunized" library; and R. Kerschbaumer (Institute for Applied Microbiology, University of Agriculture, Vienna), W. J. Harris (Department of Molecular and Cell Biology, University of Aberdeen), and R. Griep (Laboratory for Monoclonal Antibodies, Wageningen Agricultural University) for providing plasmid vectors.

\section{LITERATURE CITED}

1. Cassab, G. I., and Varner, J. E. 1987. Immunocytolocalization of extensin in developing soybean seed coats by immunogold silver staining and by tissue printing on nitrocellulose paper. J. Cell Biol. 105:2581-2588.

2. D'Arcy, C. J., Torrance, L., and Martin, R. R. 1989. Discrimination among luteoviruses and their strains by monoclonal antibodies and identification of common epitopes. Phytopathology 79:869-873.

3. Griep, R. A., Van Twisk, C., Kerschbaumer, R. J., Harper, K., Torrance, L., Himmler, G., Van der Wolf, J. M., and Schots, A. 1999. pSKAP/S: An expression vector for the production of single-chain Fv alkaline phosphatase fusion proteins. Protein Expression Purif. 16:63-69.

4. Harper, K., Kerschbaumer, R. J., Ziegler, A., Macintosh, S. M., Cowan, G. H., Himmler, G., Mayo, M. A., and Torrance, L. 1997. A scFv-alkaline phosphatase fusion protein which detects potato leafroll luteovirus in plant extracts by ELISA. J. Virol. Methods 63:237-242.

5. Harper, K., Toth, R. L., Mayo, M. A., and Torrance, L. 1999. Selection of anti-plant virus single chain variable fragments from phage display libraries. Pages 37-55 in: Recombinant Antibodies-Applications in Plant Science and Plant Pathology. K. Harper and A. Ziegler, eds. Taylor and Francis, London.

6. Harper, K., Toth, R. L., Mayo, M. A., and Torrance, L. 1999. Properties 
of a panel of single chain variable fragments against potato leafroll virus obtained from two phage display libraries. J. Virol. Methods 81:159-168.

7. Harrison, B. D. 1984. Potato leafroll virus. Commonw. Mycol. Inst./Assoc. Appl. Biol. Descrip. Plant Viruses, no. 291. Assoc. Appl. Biol., Wellesborne, United Kingdom.

8. Hoogenboom, H. R., and Winter, G. 1992. By-passing immunization: Human antibodies from synthetic repertoires of germline $\mathrm{V}_{\mathrm{H}}$ gene segments rearranged in vitro. J. Mol. Biol. 227:381-388.

9. Kerschbaumer, R. J., Hirschl, S., Kaufmann, A., Ibl, M., Koenig R., and Himmler, G. 1997. Single-chain Fv fusion proteins suitable as coating and detecting reagents in a double antibody sandwich enzyme-linked immunosorbent assay. Anal. Biochem. 249:219-227.

10. Mandecki, W., Shallcross, M. A., Sowadski, J., and Tomazic-Allen, S. 1991. Mutagenesis of conserved residues within the active site of Escherichia coli alkaline phosphatase yields enzymes with increased $k_{\text {cat }}$. Protein Eng. 4:801-804.

11. Massalski, P. R., and Harrison, B. D. 1986. Properties of monoclonal antibodies to potato leafroll luteovirus and their use to distinguish virus isolates differing in aphid transmissibility. J. Gen. Virol. 68:1813-1821.

12. Mayo, M. A., Robinson, D. J., Jolly, C. A., and Hyman, L. 1989. Nucleotide sequence of potato leafroll luteovirus RNA. J. Gen. Virol. 70: 1037-1051.

13. Mayo, M. A., and Ziegler-Graff, V. 1996. Molecular biology of luteoviruses. Adv. Virus Res. 46:413-455.

14. McCafferty, J., Griffiths, A. D., Winter, G., and Chiswell, D. J. 1990. Phage antibodies: Filamentous phage displaying antibody variable domains. Nature 348:552-554.

15. McGregor, D. P., Molloy, P. E., Cunningham, C., and Harris, W. J. 1994. Spontaneous assembly of bivalent single-chain antibody fragments in Escherichia coli. Mol. Immunol. 31:219-226.

16. Nissim, A., Hoogenboom, H. R., Tomlinson, I. M., Flynn, G., Midgley, C., Lane, D., and Winter, G. 1994. Antibody fragments from a "single pot" phage display library as immunological reagents. EMBO (Eur. Mol. Biol. Organ.) J. 13:692-698.

17. Pack, P., and Plückthun, A. 1992. Miniantibodies: Use of amphipathic helices to produce functional, flexibly linked dimeric Fv fragments with high avidity in Escherichia coli. Biochemistry 31:1579-1584.

18. Polston, J. E., Bubrick, P., and Perring, T. M. 1991. Detection of plantvirus coat proteins on whole leaf blots. Anal. Biochem. 196:267-270.

19. Roberts, I. M., Tamada, T., and Harrison, B. D. 1980. Relationship of potato leafroll virus to luteoviruses; evidence from electron microscope serological tests. J. Gen. Virol. 47:209-213.

20. Sheets, M. D., Amersdorfer, P., Finnern, R., Sargent, P., Lindqvist, E., Schier, R., Hemingsen, G., Wong, C., Gerhart, J. C., and Marks, J. D. 1998. Efficient construction of a large non-immune phage antibody library: The production of high-affinity single-chain antibodies to protein antigens. Proc. Natl. Acad. Sci. U.S.A. 95:6157-6162.

21. Susi, P., Ziegler, A., and Torrance, L. 1998. Selection of single-chain variable fragment antibodies to black currant reversion associated virus from a synthetic phage display library. Phytopathology 88:230-233.

22. Tamada, T., and Harrison, B. D. 1980. Factors affecting the detection of potato leafroll virus in potato foliage by enzyme-linked immunosorbent assay. Ann. Appl. Biol. 95:209-219.

23. Thomas, J. E. 1984. Characterization of an Australian isolate of tomato yellow top virus. Ann. Appl. Biol. 104:79-86.

24. Torrance, L. 1992. Serological methods to detect plant viruses: Production and use of monoclonal antibodies. Pages 7-33 in: Techniques for the Rapid Detection of Plant Pathogens. J. M. Duncan and L. Torrance, eds. Blackwell Scientific Publications, Oxford, United Kingdom.

25. Torrance, L., Pead, M. T., Larkins, A. P., and Butcher, G. W. 1986. Characterization of monoclonal antibodies to a UK isolate of barley yellow dwarf virus. J. Gen. Virol. 67:549-556.

26. Vaughan, T. J., Williams, A. J., Pritchard, K., Osbourn, J. K., Pope, A. R., Earnshaw, J. C., McCafferty, J., Hodits, R. A., Wilton, J., and Johnson, K. S. 1996. Human antibodies with sub-nanomolar affinities isolated from a large nonimmunized phage display library. Nature Biotechnol. 14:309-314.

27. Ziegler, A., Torrance, L., Macintosh, S. M., Cowan, G. H., and Mayo, M. A. 1995. Cucumber mosaic cucumovirus antibodies from a synthetic phage display library. Virology 214:235-238. 